\title{
INTERNAL AND EXTERNAL FACTORS AFFECTING THE SIZE OF PADDY FIELD SOLD
}

\author{
Endang Rostiana* and Yusup Fatah Hilah \\ Departement Economics, Universitas Pasundan, Bandung \\ Jalan Tamansari No. 6-8, Bandung, 40116. Indonesia \\ Telp: +62-022-4233646; Facsimile: +62-022-4208363 \\ *Corresponding E-mail: dangrostiana@unpas.ac.id
}

Recieved: March 2016; Accepted: November 2016

\begin{abstract}
This study attempted to identify internal condition of the farmers who sold their paddy field and analyze the relationship between age of the farmers, education level, number of family members, field productivity, location, and production cost with the total area of paddy field sold. This study used quantitative descriptive method. This research found that age, education level, number of family members, and location of the land had positive relation to the total area of paddy field sold. On the other hand, production cost and field productivity had negative relation to the total area of paddy field sold. Partially, field production and number of family members had no significant relation to the total area of paddy field sold.
\end{abstract}

Keywords: age, education, productivity, production cost, total area paddy field.

JEL Classification: D24

\section{INTRODUCTION}

Cianjur is one of many types of Regency in West Java Province. Cianjur Regency is well known of its quality of paddy. One of them is the tasty and perfect pandan scented, Pandan Wangi paddy. Healthy production number of paddy in Cianjur Regency has made it known as the national granary. Cianjur Regency has become the fifth biggest contributor in West Java Province.

Referring to the data from Department of Agriculture of West Java Province, in 2012 Cianjur Regency had contributed $7.3 \%$ of total paddy production in West Java Province. In 2013, it decreased to $6.9 \%$. The results were strongly supported by resource potential of Cianjur Regency, especially in its agricultural sector. Cianjur Regency has approximately $361,434.98$ hectare of area, in which 237.650 hectare of agricultural land (65.8\%) divided into two sectors, 66.180 hectare of paddy field area (27.9\%) and 171.470 hectare of non-paddy field area (72.1\%).

Economicstructure of Cianjur Regency depends on agricultural sector. Recently productivity of agricultural sector has been decreasing. It is worrisome because agricultural sector might not be the dominance sector of Cianjur Regency economy in the near future anymore.

In line with rapid growth of economy and population, Cianjur Regency government has been active in regional development. This rapid regional development led to increased demand for non-agricultual land, such as land for housing and business activities. Changes in agricultural land into non-agricultural land known as land conversion.

In one of the studies comparing conversion of prime agricultural land to non-agricultural uses in developed, developing, and less developed countries, it was said that land conversion in 


\section{Jurnal Ekonomi Pembangunan, 17 (2), December 2016, 125-135}

developed countries were more controllable than land conversion in developing and less developing countries (H. Azadi, et al., 2010).

Utomo (1992) stated that land use conversion or commonly known as land conversion was changing the function of some or all of the land area from the original function into another function that resulted in a negative impact to the environment and the land potential itself.

Irawan (2005) stated that there were three influencing factors that land conversion mostly happened to paddy fields than dry soils. First, development of non-agriculture purpose such as residential area, commercial, office building, and industrial site. They were easier to be built on flatter paddy field rather than dry soil. Second, economic infrastructure was available around paddy fields more than dry soil because of past development which focused on increasing production. Third, paddy fields were usually closer to the vilages, rather than on dry soil areas which mostly located in the hills and mountains.

Java Island is only about $6.9 \%$ of the land area of Indonesia. This island contributing to $52.32 \%$ of Indonesia's rice production. On the other side, Java Island is an island with the highest population density, resulting high pressure on the existing paddy field. For each hectare of the converted paddy field in Java Island, $2.20 \mathrm{Ha}$, new paddy field has to be developed at the outside of the island to compensate the yield loss due to decreasing productivity of the current paddy fields (Widiatmaka, et al., 2014).

Based on the experts' views, land conversion occured in Cianjur Regency was happened mostly on paddy fields especially for industrial purposes. The land conversion was focused on the north side of Cianjur Regency, mostly in Karangtengah, Ciranjang, Sukaluyu, Haurwangi, and Bojongpicung. The location of the districts are located close to big cities such as Jakarta and Bandung. Meanwhile South Cianjur location is very far from the city center with the poor road conditions (Benny, 2011).

The effect of industrial development forced the people to commit on land conversion from agricultural to non-agricultural uses, to build residential sites or other supporting facilities. Land conversion was fueled by higher buying price which attracted farmers to sell their land (Jiang, Li., et al., 2013; Feranti, N.S., 2011; Ramsey, A. F. and Corty, Floyd L., 1982). The development in housing and industrial estates, mainly in the urban periphery, has transformed prime agricultural land into large new towns and industrial estates (Firman, Tomi., 1997).

In Cianjur District Regulation No. 17 Year 2012 on Spatial Planning of Cianjur Regency in 2011-2031 article 39 paragraph 2, it is said that big Industrial Zone as referred in paragraph (1) letter a, located in Sukaluyu and Ciranjang Districts. According to Indonesian Government Regulation No. 24 Year 2009 regarding Industrial Zone, Industrial Designation Zone is a stretch of land for industrial activities based on established Spatial Planning in accordance with the provisions of the legislation. It is no surprise that many cases of land conversion were found in Sukaluyu District, especially in paddy field areas.

Based on reported data from Development of Food Crops and Horticulture Center of Sukaluyu District, throughout 2012 until 2015, there were 93 hectare or $3.9 \%$ land conversions of total area of agricultural land in Sukaluyu District. These land conversions occurred only in four of ten villages in Sukaluyu District.

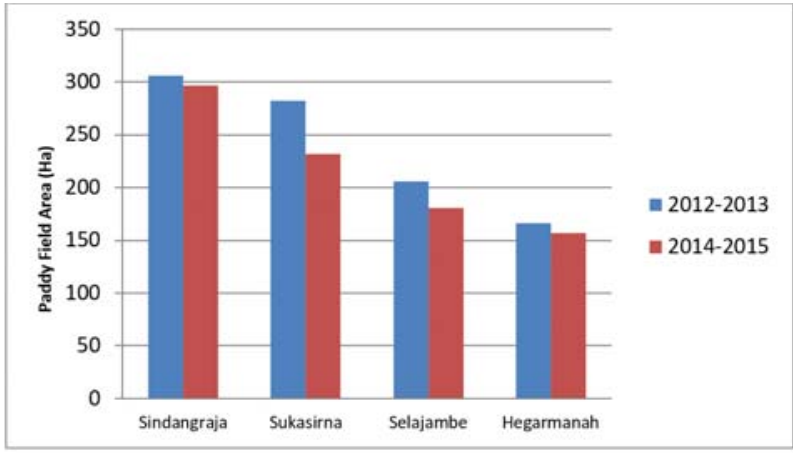

Figure 1. Paddy Field Area in Four Villages in Sukaluyu District 2012-2015

Figure 1. showed that paddy field area decreased in 2012-2015. This means that the land conversion from agricultural into non-agricultural 
uses had taken place. Sukasirna village was the one experienced the largest land conversion out of the four, as many as 50 hectare or $17.7 \%$ of total paddy field area in Sukasirna Village.

Sukasirna village is currently underway a large-scale industrial development. It has been planned that the development will be expanded and might cause an even greater land conversion in the near future. Industrial development in Sukasirna Village is one of many factors that forced the landowners to sell their lands.

Internal factors were mostly influenced by farmer's social economy household condition. Other similar research showed that economically, the main factor in determining land conversion in Tomohon, North Sulawesi, was the income, effectiveness of agricultural activity, and development of the land paddy's (Benu, Noortje. M., et al., 2013). Setiawan, B. \& Purwanto, A. (1994) stated that there were two contributing factors of land conversion from agricultural to nonagricultural uses, external and internal. Internal factors related to location and land potential (including land productivity), pattern of ownership (including land size), number of family members and income. External factors were urbanization, social and economy condition, and government policy.

In general, the land owners would not sell their agricultural land if there no driving factors rising from themselves. Internal factors played important role in decision making. Further research was necessary to assess the factors influencing the landowners to sell their agricultural land. The factors could be from internal condition of the farmers and also from natural external environment or other economic factors.

\section{Research Method}

The method used in this research was descriptive analysis method and quantitative analysis. Descriptive analysis method was used to give an explanation and interpretation of the data as well as information on the tabulation of data. Quantitative analysis method by multiple regression analysis was aimed to determine the internal and external factors influencing the farmers to sell their land.

\subsection{Operationalisation of Research Variables}

Studies on land conversion were carried out in Indonesia and some other countries as well. From earlier studies analysis, and based on supporting theories, factors influencing the sale of paddy fields in Sukasirana Village, Sukaluyu District, Cianjur Regency could be classified into two groups: internal factors and external factors.

Family internal factor was direct factor influenced by farmer's internal condition. This study covered age, education level, and number of family members. This family internal factor corresponded to some previous studies such as Allahyari, M.S.,et al.(2013), Hariri, et al. (2012), Zollinger, B., and Krannich, R.S. (2002), and Aryani (2014) among others.

External factors divided to (a) natural factor and (b) government policy. Natural factor was approached using land productivity variable. Several other studies which included land productivity as one of the variables affecting the sale or conversion of agricultural land were researches conducted by Irawan (2008), Aryani (2014), P.K. Govindaprasad and Manikandan, K. (2014), Zollinger, B., and Krannich, R.S. (2002). Government policy factor was an indirect factor as a result of government support, which led to changes in economic aspects. In present research, location of the land and cost of production were used as proxy of government's policy factors. Other studies that used land location variable as elements affecting the sale of land were researches conducted by Huang, D. (2015), Harini, et al. (2012), Putu D., et al. (2012), H. Azadi, et al. (2010).

\subsection{Sampling Method}

The sampling method used in this study was snowball sampling. Snowball sampling technique 


\section{Jurnal Ekonomi Pembangunan, 17 (2), December 2016, 125-135}

was a form of non-probability sampling method. This method was chosen because the number of population that would be studied was not known for certain. The method was done by looking for the first sample and interviewing them. Then the sample would be asked to recommend other people to be interviewed in accordance to the desired criteria, and so forth (Aryani, 2014).

Respondents in this study were the landowners who sold their paddy field for the benefit of industrial purposes in Sukasirna Village, Sukaluyu District, Cianjur Regency. There were total of 32 respondents.

\subsection{Model and Method of Analysis}

Independent variables of age, education level, and number of family member, land productivity, land location, and the cost of production of the total area of agricultural land sold were analyzed using multiple regression method with an approach to ordinary least squares (OLS). The relationship between independent variables and dependent variables had the following function:

$Y=f(U S, P D, T K, P R, L H, B Y)$

Where:

$\mathrm{Y}=$ Total area of paddy field sold

US $=$ Age (Year)

$\mathrm{PD}=$ Education Level (The level of formal education attained)

TK $=$ Number of family members (Person)

PR = Land Productivity (Ton/Ha/Harvest period)

$\mathrm{LH}=$ Land Location $(\mathrm{Km})$

$\mathrm{BY}=$ Production Cost $(\mathrm{Rp} / \mathrm{Ha} /$ Harvest period $)$

A form of regression equation was formulated from the function (1) as follow:

$$
Y=\beta_{0}+\beta_{1} U S+\beta_{2} P D+\beta_{3} T K+\beta_{4} P R+\beta_{5} L H+\beta_{6} B Y+e
$$

Where:

$\mathrm{Y}=$ Total area of paddy field sold

$\beta_{0} \quad=$ Constant value that will be obtained

$\beta_{1}-\beta_{11}=$ Regression coefficient

US $\quad=$ Age $($ Year $)$

PD = Education level (Formal education by ordinal scale)

TK $=$ Number of family members (Person)

$\mathrm{PR} \quad=$ Land productivity $(\mathrm{Ton} / \mathrm{Ha} /$ Harvest period)

$\mathrm{LH}=$ Land location $(\mathrm{Km})$

BY $=$ Production cost $(\mathrm{Rp} / \mathrm{Ha} /$ Harvest period)

$\mathrm{e}=$ Error

\section{Research Finding and Discussion}

\subsection{Descriptive Analysis}

Characteristics of respondents were described according to the following aspects: (a) gender, (b) age, (c) education level, (d) number of family members, (e) experience in farming, (f) employment outside of farming, (g) total area of agricultural land sold, (h) paddy field productivity.
Field observation showed that landowners in Sukasirna village were dominated by women. The respondents were 17 female (53.1\%) and 15 male (46.9\%). Most of the respondents had around 4-5 family members. The survey showed that $65.5 \%$ of respondents were over 50 years old and $40.6 \%$ of the respondents did not finished primary school. Age and education were two factors that determined one's mindset to make a decision to sell the paddy field.

The total area paddy field owned by the respondents were vary, most respondent (56.3\%) had 1.000-5.000 $\mathrm{m}^{2}$ and only one respondent had more than one hectare. Because they considered that their paddy field not in economic scale size, land management and irrigation problem in the future, the paddy field were sold for the benefit of industrial area.

In the last three years after the development of industrial area, grain yield tended to decrease. The average field productivity or grain yield obtained ranged from 5 to 6 tons per hectare in each harvest. Some of the respondents assumed 


\section{Jurnal Ekonomi Pembangunan, 17 (2), December 2016, 125-135}

that the industrial development had negative impacts on environment such as pollution and disturbance of the irrigation system.

The location of the land for industrial purpose was mainly located around $0.02 \mathrm{~km}-2 \mathrm{~km}$ to the main road. Other survey results showed that the majority of the lands sold were located around 0.5 to $1 \mathrm{~km}$ to the main road. If the results were compared to the nearer location of the field, which was less than $0.5 \mathrm{~km}$ to the main road, only $28.1 \%$ of the respondents had sold their land.
Cost of production was the cost incurred by the landowner or the respondent to manage the field, which consisted of expenses for seed, fertilizer, and medicine. The cost of production ranged between Rp. 1,000,000 - Rp. 2,000,000 per hectare per harvest period.

\subsection{Quantitative Analysis}

Using multiple regression technique and regression equation in equation (2), the following regression results were obtained:

Table 1. Summary of Estimated Multiple Linear Regression

\begin{tabular}{|c|c|c|c|}
\hline Variable & Coefficient & t-Statistic & Prob. \\
\hline $\mathrm{C}$ & $-1102,885$ & $-0,359906$ & 0,7219 \\
\hline US & 102,9368 & 2,982303 & 0,0063 \\
\hline $\mathrm{PD}$ & 816,7319 & 2,370773 & 0,0258 \\
\hline TK & 261,7684 & 1,373171 & $0,1819^{*}$ \\
\hline PR & $-452,5793$ & $-1,068504$ & $0,2955^{*}$ \\
\hline $\mathrm{LH}$ & 1511,859 & 2,046206 & 0,0514 \\
\hline BY & $-0,001660$ & $-2,718670$ & 0,0117 \\
\hline$R$-squared () & $=0,634919$ & Prob. (F-stat) & $=0,000145$ \\
\hline F-statistic & $=7,246321$ & $D W$-stat & $=2,909892$ \\
\hline
\end{tabular}

Note: * significant 0.05 significance level respectively

From the regression result, the equation of the regression result could be written as follow:

$\mathrm{Y}=-1102,885+102,9368 \mathrm{US}+816,7319 \mathrm{PD}+$ $261,7684 \mathrm{TK}-452,5793 \mathrm{PR}+1511,859$

LH - 0,001660 BY

Based on the result of the linear regression, hypothesis test using t-test and F-test, and other classic assumption test were tested next.

T-test were performed to calculate the regression coefficient of each independent variables so that the influence of each independent variable on the dependent variable could be determined. With $\mathrm{df}=\mathrm{n}-\mathrm{k}=32-7=25$ and $\mathrm{a}=$ $10 \%$, then the value of $t \quad 1.708$ was obtained. By comparing the value of $t$ and the value of $\mathrm{t}$, the result of independent variables were obtained, which partially significantly affected the total area of agricultural land sold. Those variables were age, education level, land location and production cost. Number of family members and land productivity variables partially had no significant effect on the total area of agricultural land sold.

F-test was performed to determine the effect of independent variables simultaneously on dependent variables. Based on the result of regression, $\mathrm{F}$ value of 7.246321 was obtained. As the $\mathrm{DF} 1 \stackrel{\text { stat }}{=} 7-1=6$, and $\mathrm{DF} 2=32-7=25$ and $\mathrm{a}=10 \%, \mathrm{~F}$ value of 2.02 was obtained. Since $F_{\text {at }}(7,246321)>F_{\text {table }}(2,02)$, this means that simultaneously, the variables of age, education level, number of family members, land productivity, land location and production cost significantly affected total area of agricultural land sold. 


\section{Jurnal Ekonomi Pembangunan, 17 (2), December 2016, 125-135}

Based on the result of regression, $\mathrm{R}^{2}$ value of 0.634919 meant that the variability of the dependent variables that may be explained by the variability of the entire independent variables were 63.5 percent, while the remaining 36.5 percent were explained by other variables outside the regression model.

In order to draw conclusion based on the result of multiple linear regression, the model equation must be free of classical assumptions. Classic assumption test in this study included normality test, multicolinearity test, heteroscedasticity test and autocorrelation test.
One of the method that was widely used for normality test was Jarque-Bera (JB) test. The test criteria was if JB $>\mathrm{X}^{2}$ then was rejected and was accepted. On the contrary if $\mathrm{JB}<$ then was accepted dan was rejected. From the test result by Jarque-Bera (JB) test, value of $\mathrm{X}^{2}$ of the $10 \%$ chi square table and $\mathrm{df}=\mathrm{k}=7$ is 12.01704 . Thus the value of Jarque-Bera $<$ or $0.989162<12.01704$, which means that residual was normally distributed.

Looking at the results of the correlation matrix of the independent variables could be done to detect whether multicolinearity symptoms were present or not.

Table 2. Results of Correlation Matrix

\begin{tabular}{ccccccc}
\hline & US & PD & TK & PR & LH & BY \\
\hline US & 1.0000 & -0.2079 & 0.4381 & 0.1644 & 0.2638 & 0.0528 \\
PD & -0.2079 & 1.0000 & -0.0348 & 0.0938 & 0.0273 & -0.0347 \\
TK & 0.4381 & -0.0348 & 1.0000 & -0.1243 & 0.4384 & -0.0326 \\
PR & 0.1644 & 0.0938 & -0.1243 & 1.0000 & 0.0134 & -0.2352 \\
LH & 0.2638 & 0.0273 & 0.4384 & 0.0134 & 1.0000 & -0.0670 \\
Y & 0.0528 & -0.0347 & -0.0326 & -0.2352 & -0.0670 & 1.0000 \\
\hline
\end{tabular}

From the table, there was no problem of multiple regression multicolinearity because the correlation matrix of each variable was less than 0.8 .

Heteroscedasticity test in this research was done using White Test. The test criteria was if Prob. Chi-Square $>a$ then no symptoms of heteroscedasticity. On the contrary if Prob. ChiSquare $<a$ then there was a heteroscedasticity symptom. The White Test showed that Prob. ChiSquare $(0.3817)>\alpha(0.1)$. It could be concluded that there was no problem of heteroscedasticity.

Breusch-Godfray or LM (Lagrange Multiplier) method was used to test whether there was a correlation between interference variables symptoms in certain periods and interference variable in other periods. The test criteria was if $R$-squared $>$ then there were symptoms of autocorrelation. On the contrary if $R$-squared < then there were no symptoms of autocorrelation. value of chi square table with $\alpha=10 \%$ and $\mathrm{df}=7$ was equal to 12.01704 . The value $R$-squared $<$ or $7.929345<12.01704$. It could be concluded that there was no autocorrelation problem.

\subsection{Relationship between Age and Total Area of Paddy Field Sold}

The age had positive and significant correlation with the size area of paddy field sold. This was consistent with the hypothesis that age positively affected total area of agricultural land sold. This means that the older the respondent, the bigger the area of paddy field sold or the younger the respondent, the smaller the area of paddy field sold. Age became a factor that could determine one's mindset to make a decision. These results were also in accordance to the opinion of Allahyari, M.S., et al. (2013) which stated that factor of age was one of the farmer's individual factors that affected how they would use their land. 
The research done by Harini, et al. (2012) stated that the variable of age did not significant affect land conversion. Comparing the research to present research, age had a positive and significant relation because most of the land owners (respondents) were people over 60 years old.

Age also closely related to a person's physical ability to do a job or productive activity. Additionally, old age was identical to having grown up children, some already married. This condition could encourage parents to immediately share their inheritance rights. Selling their paddy fields could be one of the reasons because no child wanted to continue taking care of their croplands. This was in line with research results by Zollinger, B., and Krannich, R.S. Krannich (2002) which stated that the farmers who had reached retirement age and lack of children to take care of the field were the reasons why farmers sold their agricultural land.

\subsection{Relationship between Education Level and Total Area of Paddy Field Sold}

Education level had a positive and significant correlation with total area of paddy field sold. This was not consistent with the hypothesis that level of education negatively correlated with the total area of paddy field sold. High educated farmers tend to manage their business better than low educated farmers. It could be said that high educated farmer more productive than low educated farmers. High productivity of agricultural land could be a reason for the farmers to not sell their land.

The education level significantly affected the total area of paddy field sold, while research done by Harini, et al., (2012) stated that education level variable did not significantly affect land conversion. This condition was happened because the majority of respondents who had sold their paddy field were those with low level of education.
The farmer's education level could affect the performance in managing the field. The higher the education, the more knowledge and insight they would have, that could improve their skills in managing their business. Better business management would surely have a positive impact on their income. The research results by Xaba, B.G and Masuku, M.B (2013) explained positive role of education on the farmer's profit.

Generally, the skills or the abilities of the farmer to manage agricultural land were not acquired from education, but from their experiences. With this experience, they manage agricultural land traditionally. They did not require knowledge gained from education. Thus neither high nor low levels of formal education affected the respondent's decision to sell their field.

\subsection{Relationship between Numbers of Family Members and Total Area of Paddy Field Sold}

The number of family members had a positive and not significant relation with total area of paddy field sold. This was consistent with the hypothesis that the numbers of family members have a positive relation with total area of paddy field sold. More family members increase family expenditure. It could influence the respondents to sell their field.

This result was consistent with research done by Hariri, et al. (2012). Another research conducted by Aryani (2014) stated that number of family members significantly affected the rate of land conversion. The number of family members did not significantly affect total area of paddy field sold because the burden of the family members was not a reason for the respondent to sell their field. The other reason was the respondents were old and had grown up children, even married. It caused the reduction of family members, and the income they earned from agricultural land was considered sufficient for their daily needs. 
Avalaible online at http://journals.ums.ac.id

Jurnal Ekonomi Pembangunan, 17 (2), December 2016, 125-135

\subsection{Relationship between Land Productivity and Total Area of Paddy Field Sold}

Land productivity had a negative and not significant relation with total area of paddy field sold. This was consistent with the hypothesis that land productivity had a negative correlation to total area of paddy field sold. This means that the lower the productivity of the land, the bigger the total area of paddy field sold or the higher the productivity of the land, the smaller the total area of paddy field sold. This was in accordance with the opinion of Irawan (2008) which stated that the more productive the land, the more expensive it would be.

Low land productivity caused a loss and it was possible for them to decide on selling their paddy field. This was in accordance with the opinion of P.K. Govindaprasad and Manikandan, K. (2014) which stated that when the profit margin obtained by farmer was relatively lower than investment in other sectors, farmer would begin to think of switching business. Other research results indicated that the decline in farmer's profits was a factor that caused farmer to sell their land (Zollinger, B., and Krannich, R.S., 2002).

This result was consistent with research done by Aryani (2014). The productivity of the land did not significantly affect total area of paddy field sold because the ratio between respondents who had land productivity of less than 5 and more than 5.01 tons per hectare per harvest were in balance. This showed that the productivity of the land did not significant influence the respondent to sell their farm. The other landowners who had sold their fields could be the reason and affect of the respondent to sell their field.

\subsection{Relationship between Field Site and Total Area of Paddy Field that has been Sold}

Land location had a positive and significant correlation with total area of paddy field sold. This means that the closer the location to the main road, the higher total area of paddy sold, or the further the location to the main road, the lower total area of paddy field sold. This hypothesis was in accordance with the opinion of Huang, D. (2015) which stated that the location of fertile soil in certain areas was a key factor affecting the use of land. Land location had a significant influence on whether the land was converted to other uses or not.

Significantly relation between location and total paddy sold were in line with research conducted by Harini, et al. (2012). Coefficient value that was incompatible with the hypothesis posed a problem that had to be identified. Based on the survey, the majority of the lands location that sold by the respondents were located $0.5-1$ $\mathrm{km}$ from the main road, while many lands closer to the main road had not been sold yet.

This occured because people who owned paddy field close to the main road were still maintaining their land. They will sell the land when the price of land has been in accordance with their expectations. Those who owned land close to the main road had high bargaining position. They tended to set higher price of their paddy field than the land far away from the main road.

\subsection{Relationship between Production Cost and Total Area of Paddy Field Sold}

Cost of production negatively and significant correlated with total area of paddy field sold. This was not consistent with the hypothesis that production cost had correlation with total area of paddy field sold. This means that the higher the production cost, the greater the total area of paddy field sold or the lower the production cost, the smaller the total area of paddy field sold.

Significant relation between cost of production and paddy field sold were in line with research conducted by Aryani (2014). Negative coefficient value could be explained that the most of respondent's income only from their paddy field. They did not have any other income from any other job. Even though their income had 


\section{Jurnal Ekonomi Pembangunan, 17 (2), December 2016, 125-135}

been decreased, they still cultivate their paddy field. In addition, respondents aged over 50 years old tended to have grown up and independent children which decreased the burden in the family. Their adequate income was still able to fulfill their needs. At least they still own the land that they could sell one day.

\section{Conclusion}

Sukasirna Village is one of many areas that has productive paddy field. Their agricultural crops are able to contribute to the total of paddy production in Cianjur Regency. Land conversion into industrial area in Sukasirna Village, Sukaluyu District, Cianjur Regency led to the reduction of productive land and impacted on decreasing paddy production in the future. This could occur because the more they convert or sell the land, the more farmers will lose their jobs.

Landowners who had sold their land for industrial purposes in Sukasirna Village, Sukaluyu District, Cianjur Regency were dominated by women. Most of them aged over 50 years old and had low level of formal education.

The productivity of agricultural land they earned was considered enough to fulfill daily needs. Although the burden of family members that they had to pay was quite high and the cost of production was relatively high, but they still run their paddy field. The main reasons why they keep manage their paddy field because they have no other business than as a farmer. They do not have expertise in other business except expertise in the farming, their farmland to be the only source of their livelihood.

Internal factors originating from the landowner's family could not be separated from the influence of external factors which influenced the decision to sell their paddy field. Based on the estimation of multiple linear regressions, the variables that significantly affected total area of paddy field sold were age, education level, land location and production cost. The variables of age, education level and the land location showed a positive coefficient value, while production cost showed a negative coefficient value. Variables that did not significantly affect total area of paddy field sold were the number of family members and land productivity. Numbers of family member variable showed a positive coefficient value, while land productivity variable showed a negative coefficient value.

Lack of interest in managing agricultural land due to internal factors such as decrease of productivity, increasingly expensive agricultural cost, relatively limited skills, and others could be a threat to the survival of agriculture that may involve people's lives, especially in Cianjur Regency.

Reduction of productive paddy field because of industrial area development must be followed by a policy to open the other productive agriculture lands. The policy should be supported by other policies to stimulate internal conditions of the farmers themselves so that they can be more productive.

\section{References}

Allahyari, M.S., et al. (2013),"Effective Factors on Agricultural Land Use Change in Guilan Province, Iran",Mediterranean Journal of Social Sciences, 4 (11).

Aryani, S. Devi. (2014), Analisis Dampak Alih Fungsi Lahan Pertanian Terhadap Ketahanan Pangan di Kabupaten Cianjur (Studi Kasus: Desa Sukasirna Kecamatan Sukaluyu). Tugas Akhir. Institut Pertanian Bogor.

Balai Pengembangan Budidaya Tanaman Pangan dan Holtikultura. (2015), Laporan

Luas Tanaman Padi. Kecamatan Sukaluyu. Kabupaten Cianjur.

Badan Perencanaan Pembangunan Daerah. (2011), Rencana Tata Ruang Wilayah

Tahun 2011-2031. Pemerintah Kabupaten Cianjur.

Badan Pusat Statistik. (2014),Statistik Daerah Kecamatan Sukaluyu Kabupaten Cianjur 2014. BPSKabupaten Cianjur. 


\section{Jurnal Ekonomi Pembangunan, 17 (2), December 2016, 125-135}

Badan Pusat Statistik.(2013),Hasil Sensus Pertanian 2013. BPS. Kabupaten Cianjur.

Badan Pusat Statistik . (2013),Kabupaten Cianjur Dalam Angka 2013. BPS. Kabupaten Cianjur.

Badan Pusat Statistik. (2014),Kecamata Sukaluyu Dalam Angka 2014. BPS. Kabupaten Cianjur.

Badan Pusat Statistik. (2014),Statistik Daerah Kabupaten Cianjur 2014. BPS. Kabupaten Cianjur.

Benny B. (2011),Cianjur Utara Bakal Jadi Kawasan Industri, http://ekonomi.inilah.com/ $\mathrm{read} /$ detail/1771663/cianjur-utara-bakal-jadikawasan-industri, accessed on 18 February 2015.

Benu, Noortje M. et al. (2013),"Analysis of Land Conversion and Its Impacts and Strategies in Managing Them in City of Tomohon, Indonesia",Asian Transactions on Basic and Applied Sciences, 03(02), 65-72.

Dinas Pertanian Provinsi Jawa Barat. (2015),Produksi Padi Sawah, http://diperta. jabarprov.go.id/assets/data/menu/produksi_ padi3.pdf, accessedon 28 March 2015.

Daquan, Huang, D., et al. (2015),"Factors Influencing the Conversion of Arable Land toUrban Use and Policy Implications in Beijing, China”, Sustainability, 7: 180-194.

Feranti, N.S. (2011), Pengendalian Alih Fungsi Lahan Pertanian Menjadi Non Pertanian di Kecamatan Balongbendo,http://digilib.its.ac.id/public/ ITSUndergraduate-16717-3607100003Presentation.pdf, accssed on 27 January 2016.

Firman, Tommy. (1997),"Land Conversion and Urban Development in The Northern Region of West Java, Indonesia”, Urban Studies, 34, 1027-1046.
H. Azadi, et al. (2010), "Agricultural Land Conversion Drivers: A Comparison Between Less Developed, Developing and Developed Countries",Land Degradation and Development, 22(6), 596-604.

Harini, Rika. et al. (2012),"Konversi Lahan Pertanian : Faktor-faktor dan Dampak Terhadap Kecukupan Pangan di Kabupaten Sleman”,International Journal of Geography, 44(2), 120-133.

Irawan B. (2008),"Meningkatkan Efektifitas Kebijakan Konversi Lahan”,Forum Penelitian Agro Ekonomi, 26, 116-131.

Jiang., Li., et al. (2013),"The impact of Urban Expansion on Agricultural Land use Intensity in China",Land Use Policy, 35 (2013) 33-39.

P.K. Govindaprasad \& Manikandan, K. (2014), “Agricultural Land Conversion and Food Security: A Thematic Analysis",International Research Journal of Agriculture and Rural Development, 3(1), 1-19.

Putu, Dewa. et al. (2012),"Faktor-faktor yang Mempengaruhi Alih Fungsi Lahan Studi Kasus di Subak Daksina, Desa Tibubeneng, Kecamatan Kuta Utara, Kabupaten Badung",Jurnal Agrobisnis dan Agrowisata, 1(1), 62-68.

Ramsey, A. F., and Corty, F.L. (1982), “Conversion of Prime Agricultural Land to Nonagricultural Uses in One Area of The Sunbelt",Southern Journal of Agricultural Economic, (December), 23-29

Setiawan, B. \& Purwanto, A. (1994), "Proses Konversi Lahan Pertanian di Pinggiran Kota: Studi Kasus di Daerah Pinggiran Kota Yogyakarta (Agricultural land conversion in the urban fringes: the case of fringe areas of Yogyakarta city)",Manusia dan Lingkungan. 3 (1), 79-89. 
Avalaible online at http://journals.ums.ac.id

Jurnal Ekonomi Pembangunan, 17 (2), December 2016, 125-135

Setyoko, Bayu. (2013),Faktor-faktor Yang Mempengaruhi Keputusan

Petani Mengkonversii Lahan Pertanian Menjadi Lahan Non Pertanian (Studi Kasus: Petani Desa Kopeng, Kecamatan Getasan, Kabupaten Semarang). Tugas Akhir. Universitas Diponegoro. Semarang.

Supriyadi, Anton. 2004. Kebijakan Alih Fungi Lahan dan Proses Konversi Lahan Pertanian. Fakultas Pertanian Institut Pertanian Bogor

Widiatmaka, et al. (2014),"Land Use Planning of Paddy Field Using Geographic Information System and Land Evaluation in West Lombok, Indonesia",Indonesian Journal of Geography, 46(1), 89-98.

Xaba, B.G., \& Masuku, M.B. (2013),"Factors Affecting the Productivity and Profitability of Vegetables Production in Swaziland",Journal of Agricultural Studies, 1(2).

Zollinger, B., and Krannich, R.S. (2002),"Factors Influencing Farmers' Expectations to Sell Agricultural Land for Non-Agricultural Uses",Rural Sociology, 67(3), 442-463. 